\title{
Analysis of the Levels of Organizational Culture of Academicians in Terms of Some Variables
}

\author{
Eyyup NACAR \\ Faculty of Physical Education and Sport Sciences, Firat University, Turkey. \\ Email:enacar@firat.edu.tr Tel:905324348022
}

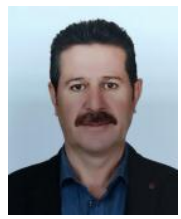

\begin{abstract}
The main purpose of this research is to examine the level of organizational culture of academicians in terms of some variables. The research universe is formed by academicians at Firat University in the 2018-2019 academic year. The sample of the study is 96 randomly selected academicians from Firat University Faculty of Education, Faculty of Humanities and Social Sciences and Faculty of Sports Sciences in the 2018-2019 academic year. The Personal Information Form was used in order to determine the demographic information of the subjects participating in the study, in addition, "Organizational Culture Scale" was used that prepared by Ogbonna and Harris (2000) and translated into Turkish by Karadeniz (2010) and developed in the master's study. The data of the research were determined to be parametric. Therefore, $t$ test and variance analysis (Anova) test was used. Tukey test and LSD test results were used to determine which groups the difference was among the results with significant differences. The error level in the study was taken as $p<0.05$. As a result of the research, academicians' organizational culture scale is based on the findings; it was found that there was no statistically significant difference in all subdimensions of the title and gender variable. There was a statistically significant difference in faculty, age group and academic study year variables.
\end{abstract}

Keywords: Organization, Culture, Academician, Education, Community Culture, Bureaucratic Culture.

Citation | Eyyup NACAR (2019). Analysis of the Levels of Organizational Culture of Academicians in Terms of Some Variables. Asian Journal of Education and Training, 5(4): 575-581. History:

Received: 5 September 2019

Revised: 9 October 2019

Accepted: 13 November 2019

Published: 16 December 2019

Licensed: This work is licensed under a Creative Commons

Attribution 3.0 License (cc)

Publisher: Asian Online Journal Publishing Group
Funding: This study received no specific financial support.

Competing Interests: The author declares that there are no conflicts of interests regarding the publication of this paper.

Transparency: The author confirms that the manuscript is an honest, accurate, and transparent account of the study was reported; that no vital features of the study have been omitted; and that any discrepancies from the study as planned have been explained.

Ethical: This study follows all ethical practices during writing

\section{Contents}

1. Introduction

2. Materials and Method 


\section{Contribution of this paper to the literature}

This study contributed to the literature, as it was thought that the organizational culture levels of academicians would add material and spiritual value to organizations by examining their levels in terms of some variables. It is thought that our research will shed light on the research estimating the organizational culture to be carried out in the future and will support science as literature in the studies on this subject.

\section{Introduction}

Nowadays, organizations are always looking for new management techniques in order to adapt to and maintain their existence as a result of technological developments and social changes. Although the technologies that succeed in organizations are quickly acquired by the organization's competitors; the strong culture of the organization creates a competitive advantage for itself.

In decisions about what is right or wrong in organizations or what is important or insignificant, the opinions expressed by the leading managers are effective for the members of the organization to decide what is right or wrong within the organization. This creates a control mechanism in the whole organization that determines how and how to behave in different units within the organization (Celiktas, 2019).

The organization is called social entities with a specific purpose, which are considered before they were established and have a specific structure, whose area of activity has been determined and linked to the outside (Daft, 2004). The organization is a structure that includes people with different social, cultural, psychological and academic characteristics. Each of these people may have different backgrounds, habits, hobbies, behavior, beliefs and values. These people may be contributing to or benefiting from the organization they are as leaders, members or stakeholders of the organization. In spite of all these differences, the organization is the structure that keeps these people together for a specific purpose or purposes, often interacting with each other and achieving the objectives of the organization that has been determined (Keyton, 2005). In order to understand how the organization does this, sociologists, anthropologists, and psychologists have examined the structure of the organization from different angles in recent years, they have created conceptual frameworks and models that are different from each other or have common allocations.

Culture has been associated with the organization by researchers and the concept of organizational culture has been uncovered, thus analyzing the organizational culture by examining the norms, shared values and fundamental of organizations, inferences have been made in areas where development, change, and management is needed. When culture is called, people often think of all the rules, values and material and spiritual beings that are collected from the past to the present. Looking at the origin word of the culture; In Latin, it appears to be derived from the words "colere" or "cultura", which means to look and grow (Sisman, 2014). It can be said that there is no universal consensus on the definition of culture. Many different researchers and writers have defined the concept of culture in different scopes and angles. In the differentiation of these definitions, it can be stated that the concept of culture is very broad and contains many intangible and tangible elements has a significant impact. According to another definition; the whole of the material and spiritual things that people create to meet their needs (Güney, 2015). According to the Güney, the culture of the organization is the most likely to be used in the culture of the is a collection of common beliefs, thoughts and values that regulate the social and economic relations of individuals in the organization and solve the problems they face (Güney, 2015). In another important definition, Deal and Kennedy defined organizational culture as a way to do and execute the work (Ozkalp and Kırel, 2018). Peters and Waterman described the organization's culture as follows: "The values shared by all members and dominant within the organization are a structure of stories, rumors, slogans and narratives in the organization, which is conveyed to employees through symbols"(Ozkalp and Kırel, 2018). Looking at all these definitions, it is seen that common characteristics are perceived as a system of thought and a series of values that bring people together and unite around common thoughts and values. Just as in the concept of social culture, organizational culture is similarly composed of elements such as beliefs, values, norms, symbols and technology. Although there may be differences between them; it can be said that the culture of the organization has a kind of micro-scale reflection and a subsystem of social culture and that there are strong relations between them (Bankacl, 2019).

Organizational culture; the purpose of the research, sometimes in the alignment and performance of the employees of the organization, sometimes in determining the changes required for the efficiency of the organization, and sometimes in the environment in which the organization is located, worked by researchers to provide benefits in areas of interest to the organization, such as identifying measures to support the organization (Bolman and Deal, 2017). Among the challenges of defining and understanding the organization's culture are the difficulties in evaluating the concept, as well as the identification and understanding of the concept requires a high level of language skills. Because people often become obsessed with cursory and lame terms that lose the true meaning of the concept and tend to impose false meanings on the concept. Even if the distinction is made well, imagination and creativity must be employed in order to understand the concept (Alvesson and Sveningsson, 2016).

A strong culture is the main determinant of the organization's success. Cultural formation in the organization; it includes several factors such as workforce, leadership, size and past. The organizational culture authorizes the manager and the workforce to use resources. An organization's culture motivates the workforce that affects the organization's performance. A strong organizational culture of open and inclusive shared values and beliefs improves communication and efficiency by providing a good working environment and coordination between employee behavior (Manyas, 2018).

When the factors that make up the culture of the organization are examined, factors such as cultural values, leaders and heroes, ceremonies and symbols, legends related to the lived organization, language, customs and norms come to the forefront. The role of these factors in the organizational culture affects the level of sophistication and awareness of that organization. Today, there are many NGOs. The leaders of these NGOs are respected in society according to the organization's history and lived legends. The demand for people's 
participation in such organizations is also high. It has been proven by research that a newly established NGO and NGOs with high history and awareness do not have the same cultural origin.

The purpose of our study; with the increasing importance of the human factor in organizations today, human emotions, thoughts, culture affecting life and behavior is also of great importance for organizations. Among the most important elements of modern societies are organizations. Since it is thought that the culture of the organization will add material and spiritual value to the organizations in the light of all these information, it is aimed to examine and investigate the levels of organizational culture of academicians.

\section{Materials and Method}

The research universe is formed by academicians at Firat University in the 2018-2019 academic year. The sample of the study is 96 randomly selected academicians from Firat University Faculty of Education, Faculty of Humanities and Social Sciences and Faculty of Sports Sciences in the 2018-2019 academic year. The Personal Information Form (name of the Faculty, title, age, gender and academic working year) was used in order to determine the demographic information of the subjects participating in the study, in addition, "Organizational Culture Scale" was used that prepared by Ogbonna and Harris (2000) and translated into Turkish by Karadeniz (2010) and developed in the master's study. Our scale consists of 16 questions and 4 sub-dimensions. When the sub-dimensions of our scale are examined, the first 4 questions refer to the innovative culture sub-size, 4 of the competing culture sub-size, 4 the bureaucratic culture sub-size, and 4 the sub-dimension of community culture. Our scale is a quintuple likert type. In the reliability analysis conducted by the Karadeniz (2010) the "innovative culture" sub-size was 0.84 , "competitive culture" sub-size 0.61 , "bureaucratic culture" sub-size for 0.83 , "community culture" sub-size for 0.76 and "Organizational Culture Scale" for the whole the coefficient of 0.90 was obtained.

\subsection{Data Analysis}

SPSS 22.0 statistical program was used to analyze the data in the study and calculate the results found. Frequency of variables (f) and percentage (\%) distributions have been calculated. It was checked by skewness and kurtosis tests to determine if the data was distributed normally. As a result of these tests and controls, the data of the research were determined to be parametric. Therefore, $t$ test and variance analysis (Anova) test was used. Tukey test and LSD test results were used to determine which groups the difference was among the results with significant differences. The error level in the study was taken as $\mathrm{p}<0.05$.

\section{Results and Interpretation}

In this section, the findings of the variables of the study are given. The findings showing the distribution of academicians in Frrat University faculty of Educational Sciences, Humanities and Social Sciences and Sports Sciences according to their personality qualities were examined and interpreted.

Table-1. Distribution table of demographic characteristics.

\begin{tabular}{|c|c|c|c|}
\hline Variable & Information form & $\mathbf{N}$ & $\%$ \\
\hline & Faculty of educational sciences & 30 & 31,3 \\
\hline \multirow[t]{5}{*}{ Faculty } & Faculty of humanities and social sciences & 51 & 53,1 \\
\hline & Faculty of sports sciences & 15 & 15,6 \\
\hline & Total & 96 & 100,0 \\
\hline & Research assistant & 21 & 21,9 \\
\hline & PhD academic member & 25 & 26,0 \\
\hline \multirow[t]{5}{*}{ Title } & Associate professor & 31 & 32,3 \\
\hline & Professor & 19 & 19,8 \\
\hline & Total & 96 & 100,0 \\
\hline & 26-35 years & 20 & 20,8 \\
\hline & $36-45$ years & 40 & 41,7 \\
\hline \multirow[t]{4}{*}{ Age } & $46-55$ years & 22 & 22,9 \\
\hline & 55 years and older & 14 & 14,6 \\
\hline & Total & 96 & 100,0 \\
\hline & Woman & 23 & 24,0 \\
\hline \multirow[t]{4}{*}{ Gender } & Man & 73 & 76,0 \\
\hline & Total & 96 & 100,0 \\
\hline & Up to 10 years & 30 & 31,3 \\
\hline & $10-20$ years & 40 & 41,7 \\
\hline Academic study & $21-30$ years & 14 & 14,6 \\
\hline \multirow[t]{2}{*}{ Year } & 31 years and above & 12 & 12,5 \\
\hline & Total & 96 & 100,0 \\
\hline
\end{tabular}

When the distribution of the demographic information of academicians in Table 1 is examined, it is seen that the highest participation is from the faculty of humanities and social sciences with $53.1 \%$, and the lowest participation is from the faculty of sports sciences with $15.6 \%$. Looking at the title information of the academicians participating in our research, when we look at the faculties of academicians participating in our research.

It was determined that $32.3 \%$ of the participants in our study were associate professors, $26 \%$ were $\mathrm{PhD}$ Academic member, $21.9 \%$ were research assistants and 19.8\% were professors. When we look at the age groups of the academicians participating in our study, we see that the most intensive participation is between $36-45$ years with $41.7 \%$ and the lowest turnout is academicians aged 55 and over with $14.6 \%$. According to gender distribution, $76 \%$ of academicians are male and $24 \%$ are female academicians. When we look at the academicians who participated in our study, we see that $41.7 \%$ of the academicians worked at the university for $10-20$ years. 
Table-2. Faculty-oriented comparison of organizational culture scale sub-dimensions.

\begin{tabular}{|c|c|c|c|c|c|c|c|}
\hline Sub-dimensions & Faculty & $\mathbf{N}$ & $\mathbf{X}$ & Ss & f & $\mathbf{p}$ & Tukey \\
\hline \multirow{4}{*}{ Innovative culture } & Educational Sciences $^{\mathrm{B}}$ & 30 & 15,63 & 2,658 & 16,294 & ,000 & \\
\hline & Humanities and Social Sciences ${ }^{A}$ & 51 & 12,17 & 3,514 & & & $\mathrm{~A}-\mathrm{B}, \mathrm{C}$ \\
\hline & Sports Science ${ }^{\mathrm{C}}$ & 15 & 16,26 & 2,763 & & & \\
\hline & Total & 96 & 13,89 & 3,634 & & & \\
\hline \multirow{4}{*}{ Competitive culture } & Educational Sciences $^{\mathrm{B}}$ & 30 & 14,70 & 2,614 & 22,825 &, 000 & \\
\hline & Humanities and Social Sciences ${ }^{\mathrm{A}}$ & 51 & 11,35 & 2,944 & & & $\mathrm{~A}-\mathrm{B}, \mathrm{C}$ \\
\hline & Sports Sciences ${ }^{\mathrm{C}}$ & 15 & 15,80 & 2,144 & & & \\
\hline & Total & 96 & 13,09 & 3,305 & & & \\
\hline \multirow{4}{*}{ Bureaucratic culture } & Educational Sciences $^{\mathrm{B}}$ & 30 & 15,40 & 2,190 & 12,132 &, 000 & \\
\hline & Humanities and Social Sciences ${ }^{\mathrm{A}}$ & 51 & 12,86 & 2,898 & & & $A-B, C$ \\
\hline & Sports Sciences ${ }^{\mathrm{C}}$ & 15 & 15,60 & 2,131 & & & \\
\hline & Total & 96 & 14,08 & 2,875 & & & \\
\hline \multirow{4}{*}{ Community culture } & Educational Sciences $^{\mathrm{B}}$ & 30 & 16,16 & 2,960 & 19,028 & ,000 & \\
\hline & Humanities and Social Sciences ${ }^{A}$ & 51 & 12,19 & 4,074 & & & $\mathrm{~A}-\mathrm{B}, \mathrm{C}$ \\
\hline & Sports Sciences ${ }^{\mathrm{C}}$ & 15 & 17,33 & 2,058 & & & \\
\hline & Total & 96 & 14,23 & 4,118 & & & \\
\hline
\end{tabular}

One way anova (Tukey), $\mathrm{p}<0.05$

In Table 2 when the faculty variable in which academicians work with the sub-dimensions of the scale of the organization culture is examined, the faculty of humanities and social sciences in the sub-dimensions of innovative culture, competitive culture, bureaucratic culture and community culture there was a statistically significant difference between academicians and academicians working in the faculty of educational sciences and the faculty of sports sciences $(\mathrm{p}<0.05)$.

Table-3. Title-axis comparison of sub-dimensions of organizational culture scale.

\begin{tabular}{|c|c|c|c|c|c|c|}
\hline Sub-dimensions & Title & $\mathbf{N}$ & $\mathbf{X}$ & Ss & $f$ & $\mathbf{p}$ \\
\hline \multirow{5}{*}{ Innovative culture } & Research assistant & 21 & 12,80 & 4,445 & 1,637 &, 186 \\
\hline & PhD academic member & 25 & 13,92 & 3,463 & & \\
\hline & Associate professor & 31 & 14,93 & 2,976 & & \\
\hline & Professor & 19 & 13,36 & 3,669 & & \\
\hline & Total & 96 & 13,89 & 3,634 & & \\
\hline \multirow{5}{*}{ Competitive culture } & Research assistant & 21 & 12,80 & 3,203 &, 485 & ,694 \\
\hline & PhD academic member & 25 & 12,72 & 3,155 & & \\
\hline & Associate professor & 31 & 13,67 & 3,636 & & \\
\hline & Professor & 19 & 12,94 & 3,170 & & \\
\hline & Total & 96 & 13,09 & 3,305 & & \\
\hline \multirow{5}{*}{ Bureaucratic culture } & Research assistant & 21 & 13,19 & 2,731 & 1,208 & ,311 \\
\hline & PhD academic member & 25 & 14,28 & 2,746 & & \\
\hline & Associate professor & 31 & 14,67 & 2,761 & & \\
\hline & Professor & 19 & 13,84 & 3,304 & & \\
\hline & Total & 96 & 14,08 & 2,875 & & \\
\hline \multirow{5}{*}{ Community culture } & Research assistant & 21 & 14,33 & 5,247 & ,551 & ,649 \\
\hline & PhD academic member & 25 & 13,60 & 3,851 & & \\
\hline & Associate professor & 31 & 14,93 & 3,520 & & \\
\hline & Professor & 19 & 13,84 & 4,113 & & \\
\hline & Total & 96 & 14,23 & 4,118 & & \\
\hline
\end{tabular}

One way anova (Tukey), $\mathrm{p}<0.05$

When the sub-dimensions of the organizational culture scale and the academic title variable were examined in Table 3 it was determined that there was no statistically significant difference in the sub-dimensions of innovative culture, competitive culture, bureaucratic culture and community culture. $(\mathrm{p}>0.05)$.

Table-4. Age-oriented comparison of organizational culture scale sub-dimensions

\begin{tabular}{|c|c|c|c|c|c|c|c|}
\hline Sub-dimensions & Age & $\mathbf{N}$ & $\mathbf{X}$ & Ss & f & p & Tukey \\
\hline \multirow{5}{*}{ Innovative culture } & 26-35 Years & 20 & 12,80 & 4,514 & 5,531 &, 002 & \\
\hline & 36-45 Years $^{\mathrm{B}}$ & 40 & 15,02 & 3,430 & & & \\
\hline & $46-55$ Years ${ }^{\mathrm{C}}$ & 22 & 14,59 & 2,538 & & & $\mathrm{~A}-\mathrm{B}, \mathrm{C}$ \\
\hline & 55 Years and above $^{\mathrm{A}}$ & 14 & 11,14 & 2,507 & & & \\
\hline & Total & 96 & 13,89 & 3,634 & & & \\
\hline \multirow{5}{*}{ Competitive culture } & 26-35 Years & 20 & 13,15 & 3,030 & 3,073 & ,032 & \\
\hline & $36-45$ Years $^{\mathrm{B}}$ & 40 & 13,87 & 3,494 & & & \\
\hline & $46-55$ Years & 22 & 13,04 & 3,015 & & & A-B \\
\hline & 55 Years and above $^{\mathrm{A}}$ & 14 & 10,85 & 2,797 & & & \\
\hline & Total & 96 & 13,09 & 3,305 & & & \\
\hline \multirow{5}{*}{ Bureaucratic culture } & 26-35 Years & 20 & 13,40 & 2,542 & 3,075 & ,032 & \\
\hline & $36-45$ Years $^{\mathrm{B}}$ & 40 & 14,90 & 2,771 & & & \\
\hline & $46-55$ Years & 22 & 14,22 & 2,202 & & & A-B \\
\hline & 55 Years and above $^{\mathrm{A}}$ & 14 & 12,50 & 3,817 & & & \\
\hline & Total & 96 & 14,08 & 2,875 & & & \\
\hline \multirow{5}{*}{ Community culture } & 26-35 Years & 20 & 14,35 & 4,987 & 4,198 & ,008 & \\
\hline & $36-45$ Years $^{\mathrm{B}}$ & 40 & 15,05 & 3,869 & & & \\
\hline & $46-55$ Years $^{\mathrm{C}}$ & 22 & 14,81 & 3,080 & & & $\mathrm{~A}-\mathrm{B}, \mathrm{C}$ \\
\hline & 55 Years and above $^{\mathrm{A}}$ & 14 & 10,85 & 3,526 & & & \\
\hline & Total & 96 & 14,23 & 4,118 & & & \\
\hline
\end{tabular}

One way anova (Tukey), $\mathrm{p}<0.05$

Total

14,23 
Table 4 also examines the age group variable of academicians working with the sub-dimensions of the organizational culture scale; when examined at the sub-dimensions of innovative culture and community culture, there was a statistically significant difference between academicians over 55 years with academicians between the ages of 36-45 and those between the ages of 46-55 $(\mathrm{p}<0.05)$. When the sub-dimensions of competitive culture and community culture were examined, it was determined that there was a statistically significant difference between those aged 55 and over and those between 36 and 45 years of age $(\mathrm{p}<0.05)$.

\begin{tabular}{|c|c|c|c|c|c|c|}
\hline Sub-dimensions & Gender & $\mathbf{N}$ & $\mathbf{X}$ & Ss & $\mathrm{t}$ & $\mathbf{p}$ \\
\hline \multirow[t]{2}{*}{ Innovative culture } & Woman & 23 & 14,13 & 3,634 & ,353 & $\overline{, 725}$ \\
\hline & Man & 73 & 13,82 & 3,656 & & \\
\hline \multirow[t]{2}{*}{ Competitive culture } & Woman & 23 & 13,21 & 3,437 & ,205 & ,838 \\
\hline & Man & 73 & 13,05 & 3,286 & & \\
\hline \multirow[t]{2}{*}{ Bureaucratic culture } & Woman & 23 & 13,56 & 2,676 &,- 991 & ,324 \\
\hline & Man & 73 & 14,24 & 2,933 & & \\
\hline \multirow[t]{2}{*}{ Community culture } & Woman & 23 & 13,43 & 4,388 & $-1,076$ &, 285 \\
\hline & Man & 73 & 14,49 & 4,028 & & \\
\hline
\end{tabular}

When we examined the sub-dimensions of the organizational culture scale and gender variable of academicians in Table 5 it was determined that there was no statistically significant difference in the sub-dimensions of innovative culture, competitive culture, bureaucratic culture and community culture ( $p>0,05)$.

Table-6. Comparison of organizational culture scale sub-dimensions with axis of academic study year.

\begin{tabular}{|c|c|c|c|c|c|c|c|}
\hline Sub-dimensions & Academic study year & $\mathbf{N}$ & $\mathbf{X}$ & Ss & $\mathrm{f}$ & $\mathbf{p}$ & LSD \\
\hline \multirow{5}{*}{ Innovative culture } & Up to 10 year $^{\mathrm{B}}$ & 30 & 12,96 & 4,303 & 2,839 & 0,42 & $\mathrm{~A}-\mathrm{B}, \mathrm{C}$ \\
\hline & $10-20$ years $^{\mathrm{A}}$ & 40 & 15,02 & 2,759 & & & \\
\hline & $21-30$ years & 14 & 14,00 & 3,234 & & & \\
\hline & 31 years and above ${ }^{\mathrm{C}}$ & 12 & 12,33 & 4,030 & & & \\
\hline & Total & 96 & 13,89 & 3,634 & & & \\
\hline \multirow{5}{*}{ Competitive culture } & Up to 10 years & 30 & 12,86 & 3,082 & ,338 & ,798 & \\
\hline & $10-20$ years & 40 & 13,40 & 3,326 & & & \\
\hline & $21-30$ years & 14 & 13,28 & 3,911 & & & \\
\hline & 31 years and above & 12 & 12,41 & 3,315 & & & \\
\hline & Total & 96 & 13,09 & 3,305 & & & \\
\hline \multirow{5}{*}{ Bureaucratic culture } & Up to 10 years & 30 & 13,73 & 2,625 & ,417 & ,742 & \\
\hline & $10-20$ years & 40 & 14,32 & 2,739 & & & \\
\hline & 21-30 years & 14 & 14,50 & 2,564 & & & \\
\hline & 31 years and over & 12 & 13,66 & 4,228 & & & \\
\hline & Total & 96 & 14,08 & 2,875 & & & \\
\hline \multirow{5}{*}{ Community culture } & Up to 10 years & 30 & 14,20 & 4,901 & 1,928 & ,131 & \\
\hline & 10-20 years & 40 & 14,67 & 3,444 & & & \\
\hline & $21-30$ years & 14 & 15,21 & 3,285 & & & \\
\hline & 31 years and above & 12 & 11,75 & 4,433 & & & \\
\hline & Total & 96 & 14,23 & 4,118 & & & \\
\hline
\end{tabular}

One way anova (Tukey), $\mathrm{p}<0.05$

Table 6 examined the sub-dimensions of academicians' organizational culture scale and the academic study year variable, and statistically between employees of 10-20 years in the innovative culture sub-dimension and those working up to 10 years and those over 31 years have been found to be significantly different $(\mathrm{p}<0.05)$. It was found that there was no statistically significant difference in other sub-dimensions $(\mathrm{p}>0.05)$.

\section{Discussion and Conclusion}

In this chapter, the findings of the academicians at Firat University who participated in the study were discussed and interpreted as to whether the levels of organizational culture differed according to some variables.

When the distribution of the demographic information of academicians in Table 1 is examined, looking at the faculties of academicians participating in our research, the highest attendance is $53.1 \%$ from the faculty of humanities and social sciences, and the lowest participation is \% With 15.6, it appears to be from the faculty of sports sciences. Looking at the title information of the academicians participating in our research, it was determined that $32.3 \%$ of the participants in our study were associate professors, 26\% were Ph.D. Academic members, $21.9 \%$ were research assistants and $19.8 \%$ were professors. When we look at the age groups of the academicians participating in our study, we see that the most intensive participation is 36-45 years of age with $41.7 \%$ and the lowest participation is academicians aged 55 and above with $14.6 \%$. According to gender distribution, $76 \%$ of academicians are male and $24 \%$ are female academicians. When we look at the academicians who participated in our study, we see that $4.1 .7 \%$ of the academicians who participated in our study worked at the university for 10-20 years.

When the academicians participating in the study were examined, the faculty variable in which they worked with the sub-dimensions of the organization's culture scale; there was a statistically significant difference between faculty of humanities and social sciences with academicians working in the faculty of educational sciences and sports sciences in terms of innovative culture, competitive culture, bureaucratic culture, and community culture sub-dimensions.

Oran (2016) according to the unit in charge, the average scores obtained from the level of employees adopting the organizational culture differ in a statistically significant way. These differences are due to the fact that 
employees working in education units have a higher attitude score than those working in administrative units (Oran, 2016).

In his study Köse (2017) said that research on the differentiation of organizational culture according to educational areas, that organizational culture in medical schools has lower values, especially innovative team culture and hierarchical culture medical schools differ edifying them to a significant extent from other faculties. The areas of education where the organization's culture is strongest are the education faculties and engineering faculties whose general organizational culture values are very close to each other. In addition, competitive culture in engineering faculties and innovative team culture in education faculties are more dominant. However, when a general assessment is made in terms of education areas, it seems difficult to talk about a general field culture such as "education faculty culture" or "engineering faculty culture" (Köse, 2017).

The main dimensions of the organization are; aims, structures, processes and organizational culture/climate. Organizational structure and processes of the institution and organizational culture should basically serve the purpose of the existence of the institution (Ozdemir, 2013). Accordingly, the development of universities as an organization; structure, process and organizational culture will depend on the harmony of the university objectives.

Universities are complex organizations formed by individuals from different subcultures of society, and these organizations, consisting of faculty members, students, and university management have their own culture (Kara, 2009).

In our research, when the sub-dimensions of the organizational culture scale of academicians and the academic title variable were examined, there was no statistically significant difference in the sub-dimensions of innovative culture, competitive culture, bureaucratic culture, and community culture.

Cevik (2016) stated that in his study, perceptions of the participants in organizational culture did not change depending on the level of education (Cevik, 2016). In the same way, Iplikci and Topsakal (2014) did not find any significant difference in organizational culture and educational status in their study with university staff.

Organizational culture is a system that shapes the modes of action and interaction within the organization and shows how things are done and helps to coexist different beliefs, values, attitudes, thoughts and morals within the organization (Simşek et al., 2008). Organizational culture is used in order to survive in a competitive environment and to respond appropriately to changing environmental conditions. Organizational culture is important in that it directs all employees to think and act collectively (Ira and Sahin, 2011).

In our study, when the age group variable of academicians working with the sub-dimensions of the organizational culture scale and the age group variable of academicians; there has been a statistically significant difference between academics over 55 with academics aged 36-45 and 46-55 years of age in the sub-dimensions of innovative culture and community culture $(\mathrm{p}<0.05)$. When the sub-dimensions of competing culture and community culture are examined; there was a statistically significant difference between the age range 55 and over and those between 36 and 45 years of age.

Kılıç and Güdük (2017) concluded that the cultural perceptions of participants in the higher age group were higher and more meaningful than those of participants in the lower age group than their cultural perceptions. It was determined that there was no statistically significant difference in the sub-dimensions of innovative culture, competitive culture, bureaucratic culture and community culture in our research when the sub-dimensions of the organizational culture scale and gender variable were examined (Kılıç and Güdük, 2017).

Bağdatlı (2015) he found that teachers' perceptions of organizational culture in their schools were equal for all types of culture, and that according to the perceptions of teachers, any type of culture in their school was not dominant compared to other types of culture. In his same study, there was no significant difference between gender, marital status, affiliated institution, age, educational status, seniority in the profession, working time at the school where they were employed, and the variables of the school type and perceptions of organizational culture (Bağdatlı, 2015).

When the sub-dimensions of the organizational culture scale of academicians and the academic year variable are examined, in the sub-dimension of innovative culture, it was found that there was a statistically significant difference between employees between 10-20 years with employees up to 10 years and employees over 31 years. It was found that there was no statistically significant difference in other sub-dimensions.

Looking at the different studies done with the organizational culture; (Bankac1, 2019) it has been found that time orientation and avoidance of uncertainty have a significant effect on the tendency to postpone academics from the lower dimensions of organizational culture. When we looked at the significant differences in demographic factors, there was a significant difference between researchers and associate professors and professors in terms of academic title, and in terms of gender, men were more they tend to postpone (Bankaci, 2019).

Ozdemir (2018) in the study of how the organization's culture is influenced by the structural variables of the organization, the structural elements such as coordination, standardization, specialization, hierarchical structure, control mechanisms and the working environment are examined it was concluded that there were significant repercussions on the culture of the organization (Ozdemir, 2018). Altinisık found that the perceptions of organizational culture of secondary school teachers did not differ significantly in the size of power culture and role culture according to the economic situation variable; the culture of success, support culture, sub-dimensions and general culture shows a significant difference in his study (Altinisık, 2017).

Universities' best way to carry out education, training and scientific research can be achieved by having a strong and good organizational culture (Köse, 2017).

As a result of the research, academicians' organizational culture; in all sub-dimensions of the title and gender variable and in the year of study, the sub-dimensions of the competing culture and community culture were found to be not statistically significant. In the age group and variable, the competing culture and community culture subsizes and age ranges between those aged 55 and over and those between 36 and 45 years old, those working between 10-20 years in the innovative culture sub-size, and those who work for up to 10 years and those who are over 31 years there was a statistically significant difference between employees. From this point of view, it may be suggested to carry out studies to provide in-depth data on the reflections of different characteristics of higher education institutions on the culture of the organization. 


\section{References}

Altinısı, A., 2017. The relationship between the organizational silence behavior of secondary school teachers and the culture of the organization. Adnan Menderes University Institute of Social Sciences Department of Educational Sciences Master's Thesis.

Alvesson, M. and S. Sveningsson, 2016. Changing organizational culture. 2nd Edn., New York: Routledge.

Bağdatll, F., 2015. Relationship between the organizational culture and conflict management styles of schooladministrators Istanbul Sabahattin Zaim University Institute Of Social Sciences Education Sciences Master's Thesis.

Bankacı, U., 2019. The impact of organizational culture on academicians' tendencies to postpone. İstanbul University Institute of Social Sciences Department of Business Administration Master's Thesis.

Bolman, L.G. and T.E. Deal, 2017. Reframing organizations: Artistry, choice and leadership. 6th Edn., New Jersey: Jossey-Bass.

Celiktas, Z., 2019. Organizational culture and organizational commitment: Beykent university institute of social sciences. Department of Business Management Organization Science, Master's Thesis.

Cevik, M.S., 2016. The impact of organizational culture on alienation. Siirt University, Institute of Social Sciences. Master's Thesis.

Daft, R.L., 2004. Organization theory and design. Ohio: South Western.

Güney, S., 2015. Organizational behavior. Ankara: Nobel Academic Publishing Education Consulting Trade. Ltd. Co.

Iplikci, F.N. and Y. Topsakal, 2014. Dimensions that determine and influence organizational culture in universities: It's an empirical study C.U. Journal of the Institute of Social Sciences, 23(2): 47-60.

Ira, N. and S. Sahin, 2011. Current and reliability study of organizational culture scale, celal bayar university. Journal of Social Sciences of the Institute of Social Sciences, 9(1): 1-14.

Kara, D., 2009. The factors causing stress in education life and the study of students attitudes in coping with stress according to their families features. Selçuk University Journal of the Institute of Social Sciences, 22(1): 255-263.

Karadeniz, D., 2010. An examination of the organizational culture in terms of organizational commitment and intention to remain in the organization. Abant İzzet Baysal University, Institute of Social Sciences, Department of Public Administration, Master's Thesis.

Keyton, J., 2005. Communication \& organizational culture: A key to understanding work experiences. Los Angeles: Sage.

Kılıç, C.H. and Ö. Güdük, 2017. Evaluation of outsourcing in health care in the context of corporate culture: It's a hospital sample. Journal of Health Scholars, 4(2): 81-89.Available at: https://doi.org/10.5455/sad.13-1490969429

Köse, M.F., 2017. The relationship between organizational culture and academic performance in universities. Gazi University Institute of Educational Sciences Department of Educational Sciences Ph.D. Thesis.

Manyas, S., 2018. The relationship between organizational culture and organizational commitment: A study on istanbul university employees. Istanbul Gelisim University Institute of Social Sciences Department of Business Administration, Master's Thesis.

Ogbonna, E. and L.C. Harris, 2000. Leadership style, organizational culture and performance: Empirical evidence from UK companies. International Journal of Human Resource Management, 11(4): 766-788.Available at: https://doi.org/10.1080/09585190050075114.

Oran, A., 2016. Examining organizational culture in higher education institutions in terms of organizational commitment and job satisfaction levels of employees. Aksaray University Institute of Social Sciences Department of Business Administration. Master's Thesis.

Ozdemir, E., 2018. Examination of organizational culture in terms of structural variables in a higher education institution. Eskisehir Osmangazi University Institute of Educational Sciences Department of Higher Education Management and Policy Higher Education Management Master's Thesis.

Ozdemir, S., 2013. Turkish education system and school management. Ankara: Pegem.

Ozkalp, E. and Ç. Kırel, 2018. Organizational behavior. Bursa: Ekin Printing Publication Distribution, 8.

Simşek, M.S., T. Akgemci and A. Celik, 2008. Introduction to behavioral sciences and behavior in organizations. 6th Edn., Print, Ankara: Gazi Bookstore.

Sisman, M., 2014. Organizations and Cultures. Istanbul: Pegem Academy, 4. 